\title{
Can Dependence on Special Autonomy Funds Solve Poverty?
}

\author{
Marfian Rizky Ersanta ${ }^{1}$, Nirdukita Ratnawati ${ }^{2}$ \\ \{ersanta.marfian@gmail.com ${ }^{1}$, nirdukita.ratnawati@trisakti.ac.id² $\left.{ }^{2}\right\}$ \\ Universitas Trisakti, Jakarta, Indonesia
}

\begin{abstract}
Aceh Province as one of the provinces that has high poverty in Indonesia has a special characteristic with the Special Autonomy Fund transferred from the Central Government. However, the poverty rate in Aceh Province is $15 \%$, far from the national poverty average of $9.2 \%$ in 2019 . Therefore, the aim of this study is to determine the effect of Regional Original Income, Special Autonomy Funds, and Gross Regional Domestic Product to the number of poor people in 23 Regencies / Cities in Aceh Province. This research uses panel data regression analysis method with Fixed Effect Model. The results of the study show that local revenue and Gross Regional Domestic Product has a significant effect on reducing poverty in districts / cities in Aceh Province. Meanwhile, the Special Autonomy Fund has a positive and significant impact on poverty in 2011-2019 which needs to be studied further in terms of its causes.
\end{abstract}

Keywords: Special Autonomy Fund; Gross Domestic Regional Product; Poverty

\section{Introduction}

Aceh Province is one of the provinces in Indonesia which has a very high poverty rate and is the 5th poorest province nationally. The poverty rate in Aceh Province in 2019 was 15\%, far from the national average poverty rate of $9.2 \%$. Poverty reduction performance in Aceh Province is also relatively stagnant. Although the percentage has decreased, the number of poor people has not decreased too much. The percentage of poor people to the total population is decreasing due to an increase in the number of people that occurs from year to year which is bigger as shown in Figure 1. 


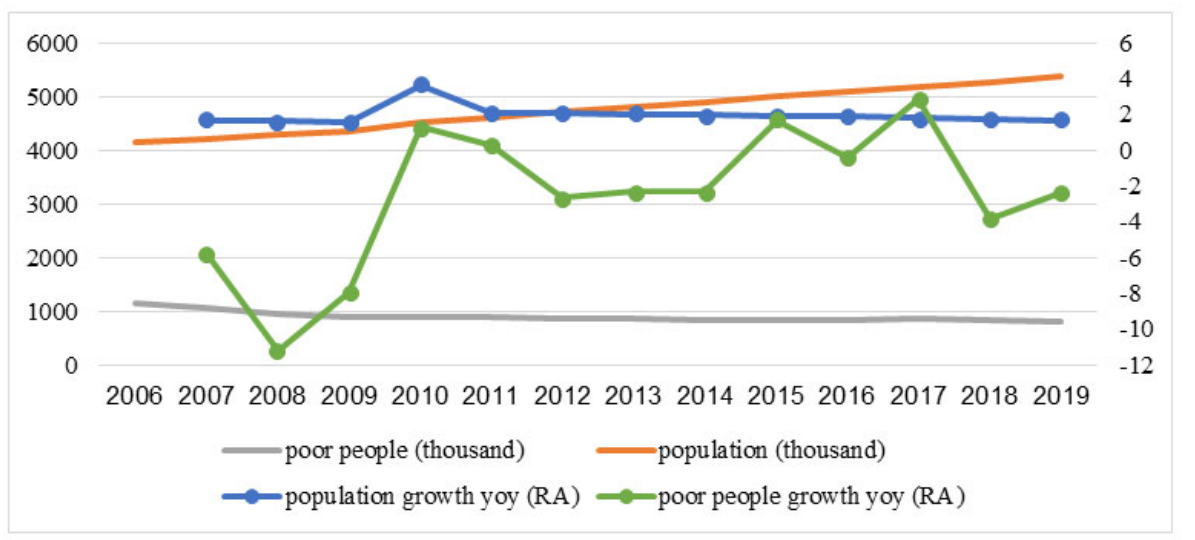

Fig. 1. Aceh Province's Population and Poor Rate (BPS, processed, 2021)

This situation becomes even more ironic when we see the amount of fiscal wealth owned by Aceh Province. The Regional Revenue and Expenditure Budget (APBD) of Aceh Province based on the publication of the Ministry of Finance in 2019 reached 15 Trillion Rupiah and is the 5th largest APBD, after Central Java, although Aceh Province's fiscal dependence on the Central Government is also very high. The composition of Regional Original Revenue (PAD) is only $17 \%$, while the rest is transfer funds from the central government with a composition of $30 \%$ of the Balancing Fund and $50 \%$ more of the Special Autonomy Fund.

The existence of economic inequality at the edge of Indonesia's territory led to disintegration conflicts that gave rise to separatist groups, such as in Aceh Province where the Free Aceh Movement (GAM) emerged and Papua Province where the Free Papua Organization (OPM) emerged. One form of government anticipation to prevent separatism from occurring is to implement asymmetric decentralization for Aceh and Papua, in the form of Special Autonomy. For asymmetrical decentralization in Aceh, the government has put it in Law Number 11 of 2006 concerning the Government of Aceh. Article 183 explains that the Special Autonomy Fund is intended to finance development, improve the people's economy, reduce poverty, improve the quality of education and health. The allocation of the Special Autonomy Fund for Aceh Province based on the rules will be given for 20 years. In the first 15 years the amount was $2 \%$ of the ceiling of the National General Allocation Fund (DAU), while for the last 5 years the amount was equal to $1 \%$ of the ceiling of the National DAU (UU No. 11/2006).

The Aceh Special Autonomy Fund has been provided since 2008, and in 2019 its value was realized to reach 8.4 Trillion Rupiah. Every year the realization of Special Autonomy funds also far exceeds the Aceh Province Original Revenue as shown in Figure 2. 


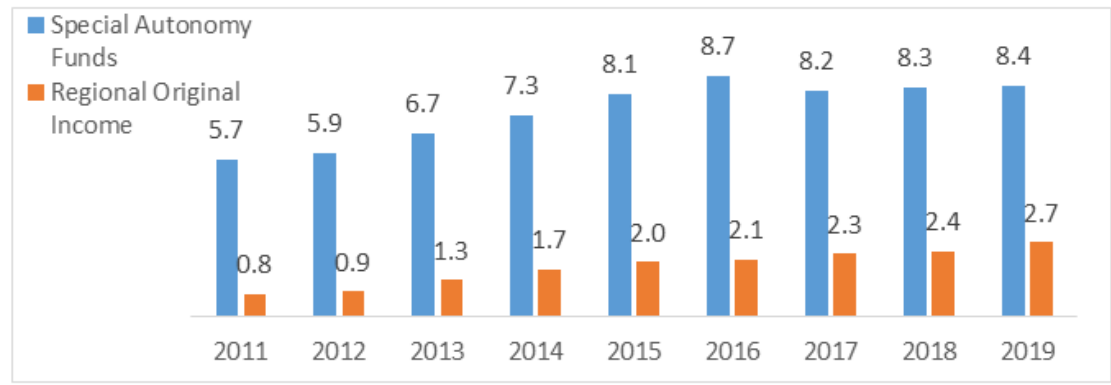

Fig. 2. Realization of Special Autonomy Fund and Aceh Province Original Income 2011-2019 - in Trillion Rupiah (Ministry Of Finance, processed, 2021)

The Special Autonomy Fund is expected to provide community welfare and reduce poverty, as research by Musliadi and Abdul Halim revealed that the Special Autonomy Fund had an influence on poverty reduction in 23 regencies/cities in Aceh Province in 2008-2012 [1]. On the other hand, there are several research results which reveal that the Special Autonomy Fund does not significantly reduce poverty, such as the results of research from Muhammad Kadafi and Murtala who reveal that the Special Autonomy Fund does not have a significant effect on the poverty level of Aceh Province in 2010-2017 [2].

With the existence of Regional Autonomy, regional governments must also be more observant in exploring Regional Original Income, which is one source of financing for development, government operations, and to fulfill services to the people in their regions. Regional income is an important part of an area because it can be used to implement programs planned by the government for the welfare of the community [3]. In addition to the encouragement from the fiscal side, the size of the economy of a region must also be increased, which is reflected in the size of the Gross Regional Domestic Product (GRDP). Ideally, a larger GRDP can reduce poverty levels

\section{Literature Review}

\subsection{Poverty}

Poverty is a condition of a person who has limitations in fulfilling his basic rights in order to survive and have a dignified life, while what is meant by basic rights include adequate food needs, guaranteed health, quality of education, availability of jobs, decent housing, clean water, land, natural resources and a protected environment, a sense of security from the threat of violence, and the right to interact in social and political life. To measure the fulfillment of the basic rights of the poor, Bappenas uses approaches including: basic needs approach, income approach, human capability approach and objective subjective approach (Bappenas in Muammar Ramadhan \& Cahyono, 2019).

\subsection{Concept of Decentralization and Regional Autonomy}

There are two patterns that can be applied within the framework of the Unitary State, the pattern of centralization and decentralization patterns. In a centralized pattern, the entire 
territory of the country is in the same administrative and legal area. Meanwhile, in the decentralization pattern, there are a number of delegations of authority from higher government to regional governments which do not change the basic concept of a unitary state [5]. The rationale for implementing decentralization is to realize better public services and to realize a decision-making mechanism for the community that is more characteristic of the nature of democracy. In the process of transferring responsibility from higher government to lower government for the provision of services, things can be counterproductive if it is not followed by financial decentralization, as a form of support for the transfer of responsibility. In this case, financial decentralization in government also applies the money follow function principle [6].

There are two basic categories of decentralization, namely symmetrical decentralization and asymmetrical decentralization, or better known as special autonomy. Joachim Wehner said that the existence of different autonomy in one region from another is a natural thing in the administration of government in various countries. This pattern works well in both a unitary state with decentralization and a federative state (Djojoseoekarto in Sanur, 2020). Through the existence of UU No. 18 of 2001 concerning Special Autonomy for the Province of the Special Region of Aceh and UU No. 21 of 2001 concerning Special Autonomy for the Province of Papua, the use of the term special autonomy began to be used in Indonesia.

The issue of financial distribution is also an important issue in the implementation of Aceh's special autonomy. In UU number 18 of 2021, the distribution of finance between the regions and the center is described in more detail and the formula is different when compared to UU number 25 of 1999. The calculation of granting Aceh special autonomy funds is based on a percentage of the total general allocation fund (DAU) and is carried out in stages. For the first 15 years it is 2 percent of the DAU, and for the next 5 years it is 1 percent of the DAU. Through the provision of Special Autonomy funds, the goal to be achieved is to increase the welfare of the Acehnese people from the results of natural resources that are managed and utilized. There are four priority programs to improve the welfare of the Acehnese people, namely education, health, people's economic empowerment, and infrastructure development. This is stated in Article 179 paragraph (2) of UU No. 11 of 2006

If we look further, the difference in the financial balance between Aceh province and other provinces is understandable, considering Aceh is contribute very large foreign exchange to the country but the level of welfare of the Acehnese people has not increased too much. From 1961 to 1991 there were 450 oil wells in East Aceh and were mined by the Canadian Assamera Oil Company. Then since the discovery of liquefied natural gas fields in North Aceh Regency in the early 1970s, Aceh's economy has experienced rapid growth. Pertamina, Mobil Oil Indonesia and Jilco Japan built a liquefied natural gas refinery through a joint venture that was established in 1977 under the name PT Aron NGL. Since then, Aceh has exported natural gas to Taiwan, Korea and Japan. Seeing the success of the construction of PT Arun NGL, the construction phase of the Lhokseumawe Industrial Zone (ZILS) was also started. After the success of the LNG plant, and to utilize LNG, not long ago a fertilizer factory and the Asean Aceh Fertilizer (AAF) were established which produce fertilizer exports to increase the country's foreign exchange. In 1991, almost $90 \%$ of PT PIM and PT AAF's fertilizer output was directed to export [8].

Regional governments within the framework of regional autonomy are given a greater role in development and are encouraged to be more independent in efforts to obtain financing for their regional operational activities. Regional Original Revenue and Regional Expenditure are interrelated matters, and are set forth in a single budget allocation, and compiled as a tool for running the government. Local governments also have functions and responsibilities to 
improve people's welfare through development efforts in various fields. Regional Original Revenue (PAD) is the income obtained by the region from the results of regional taxes, regional levies, separated regional wealth management, and other legitimate regional original revenues. The purpose of local revenue is to be able to provide flexibility for regions to obtain funding in implementing policies in their regions, as well as implementing regional autonomy as a form of embodiment of the principle of decentralization [9].

The success of a development can be measured through economic growth [10] . In a development, one of the most important goals is to reduce the level of poverty which is realized from economic growth and from the redistribution of income. Economic growth is something important, but there are things that are more important than just the rate of growth, that is who creates economic growth, whether most people or only a few people. Economic growth cannot reduce poverty and inequality if it is only enjoyed by a small number of people. If a large part of society contributes to economic growth, it will have an impact on reducing poverty and inequality between the poor and the rich [11].

\section{Research Method}

In writing this study, the authors conducted a descriptive and quantitative analysis. Descriptive analysis is used in the explanation of the dynamics of the variables and the related data is presented in the form of certain graphics or tables, so that it can provide a broader explanation. The quantitative analysis method used is an econometric analysis of panel data regression using 3 independent variables, namely Regional Original Income, Special Autonomy Funds, Gross Regional Domestic Product, while the dependent variable is the number of poor people. The relationship of each of these variables can be formulated as follows:

$\log$ Poor $_{\text {it }}=\beta_{0}+\beta_{1} \log \mathrm{PAD}_{\mathrm{it}}+\beta_{2} \log \mathrm{OTSUS}_{\mathrm{it}}+\beta_{3} \log \mathrm{GRDP}_{\mathrm{it}}+\mathrm{e}_{\mathrm{it}}$

Where:

Poor $_{\text {it }}=$ Number of poor people subject-i year- $\mathrm{t}$

$\mathrm{PAD}_{\mathrm{it}}=$ Locally generated revenue subject-i year- $\mathrm{t}$

OTSUS $_{\text {it }}=$ Special Autonomy Funds subject-i year-t

GRDP $_{\text {it }} \quad=$ Gross Regional Domestic Product subject-i year-t

$\beta_{0} \quad=$ Constanta/Intercept

$\beta_{\mathrm{i}} \quad=$ Regression Coefficient $(\mathrm{i}=1,2,3)$

$\mathrm{e}_{\mathrm{it}} \quad=$ error

The data used in this study were obtained from the publications of the Central Statistics Agency and the Ministry of Finance, covering 23 regencies/cities in Aceh Province in 20112019. To obtain the best model in panel data analysis, it is necessary to go through several stages of testing, including: Chow Test, Hausman Test, and LM Test. If the Hausman test results in the choice of a fixed effect model, then the LM test cannot be carried out [12]. 


\section{Results and Discussion}

\subsection{Descriptive Analysis}

The average number of poor people (mean) in districts/cities in Aceh Province in 20112019 was 37.21 thousand people, while the median value was 29.99 thousand people. The highest number of poor people (maximum) was in North Aceh Regency in 2011 which was 124.66 thousand people. The least (minimum) poor population is in Sabang City in 2019 which is 5.43 thousand people.

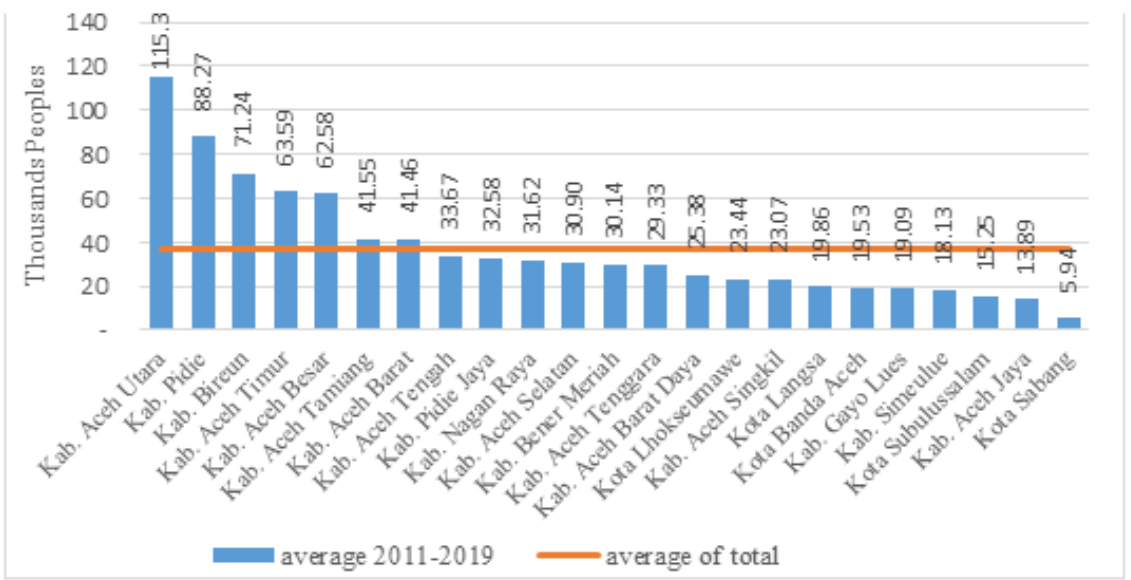

Fig. 1. Average Number of Poor Population in 2011-2019 Districts/Cities in Aceh Province (BPS, processed, 2021)

Based on the 2020 BPS publication of Aceh Province, as table 1, in general, poverty in Aceh occurs in areas with a high population, and mainly occurs in rural areas. Poor households in Aceh generally have a large number of household members and the head of the household have low education. In poor families, many household heads do not have jobs or work in the agricultural sector.

Table 1. Characteristics of Poor Households and Non-Poor Households in Aceh Province, March 2019 (BPS, 2020)

\begin{tabular}{lcc}
\hline & $\begin{array}{c}\text { Poor } \\
\text { household }\end{array}$ & $\begin{array}{c}\text { Non- Poor } \\
\text { household }\end{array}$ \\
\hline Average number of household members (person) & 5.00 & 4.00 \\
Percentage of female household heads & 20.38 & 19.76 \\
Average age of head of household (years) & 48.78 & 47.92 \\
Average length of schooling for the head of household (years) & 6.84 & 8.70 \\
Education level of head of household (\%) & & \\
a. Not completed in primary school & 23.93 & 17.95 \\
b. Primary School & 36.89 & 26.65 \\
c. Junior high school & 20.84 & 18.08 \\
d. Senior High School & 17.31 & 26.40 \\
$\quad$ e. College & 1.03 & 10.92 \\
Main source of household income (\%) & & \\
\hline
\end{tabular}




\begin{tabular}{lcc}
\hline & $\begin{array}{c}\text { Poor } \\
\text { household }\end{array}$ & $\begin{array}{c}\text { Non- Poor } \\
\text { household }\end{array}$ \\
\hline a. Does not work & 16.10 & 13.21 \\
b. Agriculture & 49.54 & 37.23 \\
c. industry & 3.90 & 4.19 \\
d. Others & 30.46 & 45.38 \\
\hline
\end{tabular}

The average (mean) PAD of districts/cities in Aceh in 2011-2019 was 83,462.29 million Rupiah. While the median value is 59,329.69 million Rupiah. The highest Regional Original Income (maximum) was in North Aceh Regency in 2016 which was 388,251.8 million Rupiah, while the lowest PAD (Minimum) occurred in Subulussalam City in 2012 of 6,825.44 million Rupiah. If we look in more detail at the components that make up PAD in 3 regencies/cities with the highest PAD and 3 regencies/cities with the lowest PAD, as shown in Figure 4, in general, local revenue has a small portion of regional revenue, and when viewed in more detail, regional taxes and regional levies only have a small portion of the Regional Original Revenue component.

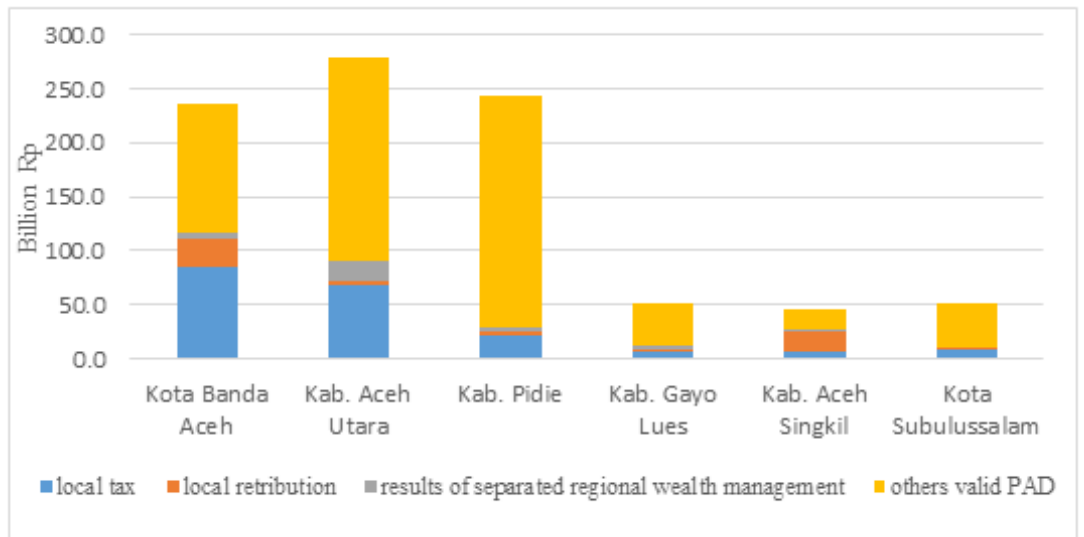

Fig. 2. Components of PAD 6 Districts/Cities in Aceh Province in 2019

(Kemenkeu, processed, 2021)

The average (mean) of the District/City Special Autonomy Fund in Aceh Province in 2011-2019 was 145,316.42 million Rupiah. While the median value is 97,391.45 million Rupiah. The highest Special Autonomy Fund was in North Aceh Regency in 2019 which was 750,904.76 million Rupiah, while the lowest Special Autonomy Fund was in East Aceh Regency in 2016 which was 5,000 million Rupiah. In the 2020 DPR RI BAKUN study with the title Review of the Special Autonomy Fund for Aceh Province, as in table 2 it is known that the allocation for the use of the Special Autonomy funds is greatest for infrastructure with an average of 2014-2019 amounting to $45.32 \%$, then Education $21.15 \%$, and Health $13.02 \%$. Meanwhile, the specific allocation for Poverty Reduction is only $5.37 \%$. 
Table 2. Special Autonomy Fund Allocation for Aceh Special Autonomy Priority Sector (DPR RI's BAKUN Study, 2020)

\begin{tabular}{|c|c|c|c|c|c|c|c|}
\hline \multirow[t]{2}{*}{ Field } & \multicolumn{6}{|c|}{ Year (Billion Rp) } & \multirow{2}{*}{$\begin{array}{c}\text { Average } \\
(\%)\end{array}$} \\
\hline & 2014 & 2015 & 2016 & 2017 & 2018 & 2019 & \\
\hline Infrastructure & 3521.20 & 3219.87 & 3710.64 & 2867.35 & 3643.75 & 3262.39 & 45.32 \\
\hline $\begin{array}{l}\text { People's Economic } \\
\text { Empowerment }\end{array}$ & 548.56 & 775.59 & 961.39 & 941.53 & 767.25 & 788.22 & 10.95 \\
\hline Poverty Reduction & 166.27 & 168.81 & 183.36 & 412.42 & 462.34 & 386.61 & 5.37 \\
\hline Education & 1569.85 & 1677.46 & 1582.49 & 2014.28 & 1624.27 & 1522.50 & 21.15 \\
\hline Social & 165.72 & 213.54 & 131.02 & 218.23 & 147.90 & 165.80 & 2.30 \\
\hline Health & 806.80 & 889.48 & 956.62 & 1280.06 & 1178.77 & 937.06 & 13.02 \\
\hline Aceh Specialties & 45.88 & 112.99 & 181.69 & 237.78 & 205.51 & 135.93 & 1.89 \\
\hline Total & 6824.28 & 7057.74 & 7707.21 & 7971.65 & 8029.79 & 7198.50 & \\
\hline
\end{tabular}

The average (mean) GRDP of districts/cities in Aceh Province in 2011-2019 is 5,025,683.76 million Rupiah. While the median value is 3,740,292.79 million Rupiah. The highest Gross Regional Domestic Product was obtained by North Aceh Regency in 2012 which was 18,151,766.38 million Rupiah, while the lowest Gross Regional Domestic Product was found in Sabang City in 2011 which was 774,469.42 million Rupiah.

If we divide GRDP by the total population, it will produce GRDP per capita. GRDP per capita in 2019 in Regencies/Cities in Aceh Province as shown in Figure 5. The average GRDP per capita in 2019 in Aceh Province is 24.2 million Rupiah a year. There are only 8 regencies/cities in Aceh Province whose GRDP per capita is above the average. North Aceh Regency, which has the highest average GRDP, is only slightly above the average, which is 27.3 million Rupiah in 2019, while the City of Sabang which has the lowest average GRDP, has a fairly high GRDP per capita, which is 32.6 million Rupiah in 2019. This shows that the large population density reduces the economic size of a region

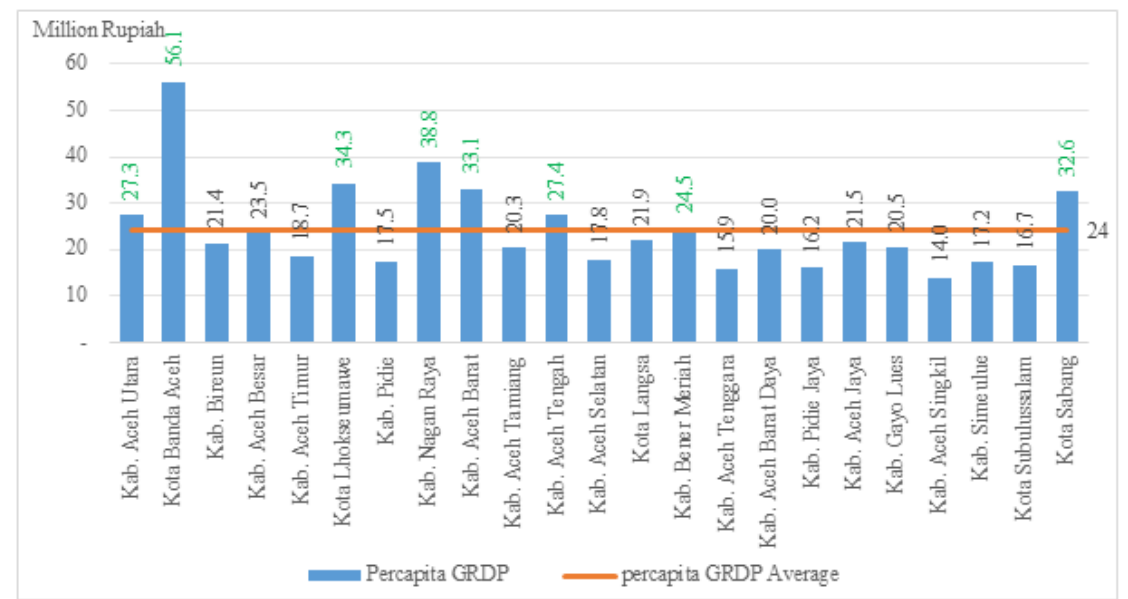

Fig. 3. GRDP Per capita District/City in Aceh Province in 2019 (BPS, 2021)

In general, in 2019 the economy in Aceh Province was supported by agriculture and trade. Based on the BPS release as presented in Figure 6, it is known that Agriculture, Forestry and 
Fisheries have a share of $27.8 \%$; Wholesale and retail trade, repair of cars and motorcycles by $15.4 \%$; and construction by $9.5 \%$. The remaining half contains other business fields.

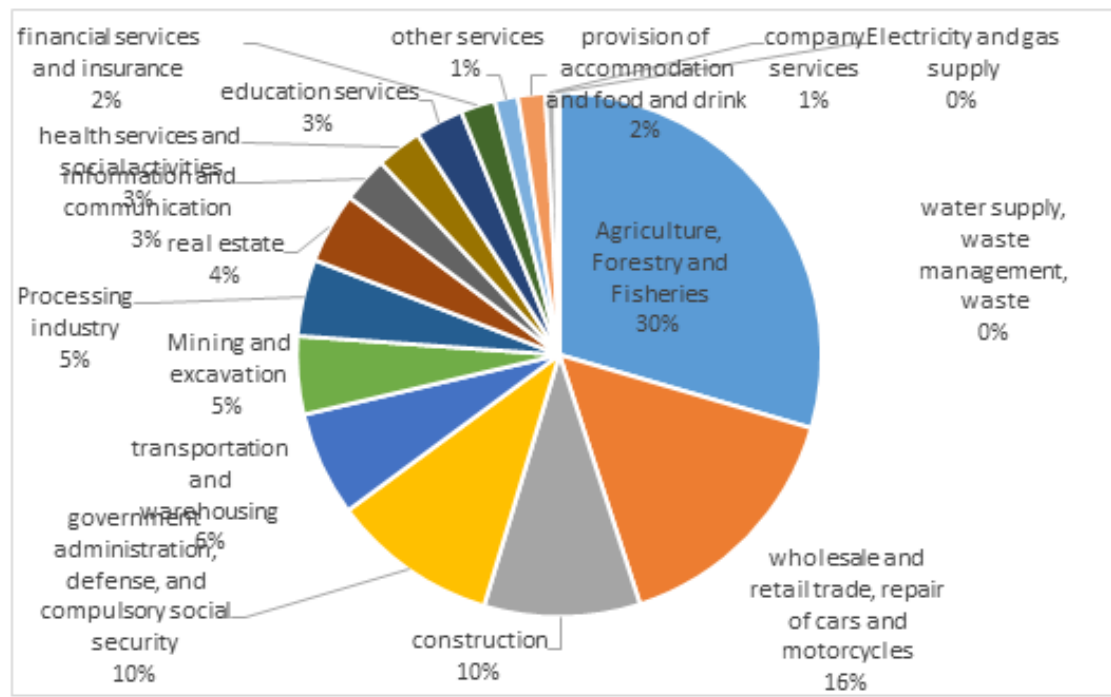

Fig. 4. Share of GRDP in Aceh Province's Business Fields in 2019 (BPS, processed, 2021)

\subsection{Statistical analysis}

To determine the best model for panel data estimation, the Chow test and Haussman test were carried out. Based on the calculation results of the Chow test, the probability value of 0.0000 is smaller than $=5 \%(0.05)$, meaning that it rejects the hypothesis to use the Common Effect model and accepts the hypothesis to use the Fixed Effect model. The Haussman test results show a probability value of 0.0000 which is smaller than $=5 \%(0.05)$ which means that it accepts the hypothesis to use the Fixed Effect model. Thus, the model in this study selected is the Fixed Effect. After selecting the best model, and selecting the Fixed Effect Model, the estimation results are as follows:

Table 3. Hasil Estimasi Fixed Effect Model (Eviews, 2021)

\begin{tabular}{lcc}
\hline \multicolumn{1}{c}{ Variabel } & Coefficient & T-statistic \\
\hline Constanta & 4.795325 & $7.720590^{*}$ \\
LnPAD & -0.029246 & $-3.791481^{*}$ \\
LnOTSUS & 0.013265 & $2.662699^{*}$ \\
LnGRDP & -0.080535 & $-1.801436^{* *}$ \\
* Significant at Degree of Freedom $5 \%$ \\
** Significant at Degree of Freedom $10 \%$ \\
Adj $R^{2}$ & 0.994879 \\
F-statistic & 1601.938 \\
Sum square resid & 0.395931 & \\
\hline
\end{tabular}

The amount of R-squared indicates the extent to which the independent variable can explain the dependent variable in the research model used. The R-squared value in the model is 0.995501 , it can be stated that the 99.55 percent change in the dependent variable (Number 
of Poor Residents in the District/City of Aceh Province) can be explained by the independent variables in the model, the remaining 0.45 percent explained by other variables outside the model. F-Statistic testing is intended to obtain information whether the independent variables simultaneously significantly affect the dependent variable used in the research model. The calculation results obtained a probability value (F-Statistic) of 0.0000 which is smaller than the real level of 5 percent. With a confidence level of 95 percent $(1-\alpha)$ it can be concluded that the independent variables used in the model jointly significantly affect the dependent variable.

\section{a) The Effect of Regional Original Income on Poverty}

Regional Original Income has a negative coefficient and has a significant effect on the number of poor people, which is worth -0.029246 , which means that the greater the Regional Original Income, the less the number of poor people. Similar results were also presented by Musliadi \& Abdul Halim (2015) who in their research revealed that Regional Original Income produced a negative and significant coefficient on poverty in research in 23 Districts/Cities of Aceh Province in 2008-2012 [1]. In another study conducted by Jolianis (2016) in Districts/Cities in West Sumatra Province, the results showed that there was a negative and significant effect of Regional Original Income on Poverty [13].

Sensitively, the poverty variable is not responsive to changes in Regional Original Income. This is indicated by the elasticity value of the Regional Original Income variable of 0.029246 , which explains that every $1 \%$ increase in Regional Original Income only reduces poverty by $0.03 \%$, so it is inelastic. This means that if there is a large increase in Regional Original Income in 23 Regencies/Cities in Aceh Province, it will only reduce the number of poor people relatively small.

\section{b) The Effect of the Special Autonomy Fund on Poverty}

The Special Autonomy Fund has a positive and significant coefficient on the number of poor people, which is worth 0.013265 , which means that if the Special Autonomy Fund increases by one percent, the number of poor people will increase by 0.013 percent from before, cateris paribus. This result is also not in accordance with the theory and objectives as stated in the law. The Special Autonomy Fund should be able to stimulate and even make a major contribution to improving welfare and reducing the number of poor people.

Another study by Muhammad Kadafi and Murtala (2020) which examined the effect of PAD, DAU, and the Special Autonomy Fund on poverty in Aceh Province in 2010-2017, obtained research results showing that the Special Autonomy Fund had no effect on poverty with a negative regression. 0.328690 but not significant. According to Kadafi and Murtala (2020) the Special Autonomy Fund has no effect on Poverty because the distribution and use of these funds misses the target [2]. Another study by Muhammad Mantsani, et al (2019) with the title "Determinants of Poverty in Aceh Province in 2017" shows that the Special Autonomy Fund variable with a coefficient of 1.897 does not have a significant effect on poverty [14].

\section{c) The Effect of GRDP on Poverty}

The Gross Regional Domestic Product variable has a negative coefficient of 0.080535 and has a significant effect on the number of poor people. This means that if the Gross Regional Domestic Product increases by one percent, the number of poor people will decrease by $0.08 \%$ 
percent from before, cateris paribus. The results of this study are also similar to research by Muhammad Mantsani et al (2019) which examined the factors that influenced Aceh's poverty in 2017 and found that GRDP had a negative coefficient of 2,251 and was significant for poverty [14].

Sensitively, the poverty variable is not responsive to changes in Gross Regional Domestic Product. This is indicated by the elasticity value of the Gross Regional Domestic Product variable of 0.080535 , which explains that every 1\% increase in Gross Regional Domestic Product only reduces $0.08 \%$ of poverty, so it is inelastic. This means that if there is a large increase in Gross Regional Domestic Product in 23 regencies/cities in Aceh Province, it will only reduce the number of poor people relatively small.

\section{Conclusion}

Based on the results of research and discussion, the conclusions obtained:

a. Regional Original Income in the Regency/City of Aceh Province has a small portion in Regional Revenue. Meanwhile, when viewed in more detail, Regional Taxes and Regional Levies only have a small portion of the Regional Original Revenue component. The largest allocation for the use of Special Autonomy funds is on infrastructure, while the specific allocation for poverty reduction is very small. In terms of the GRDP sector, the biggest ones are Agriculture and Trade. Poverty in Aceh occurs in areas with a high population, and mainly occurs in rural areas with low educational characteristics and unemployment problems.

b. Regional Original Income has a negative and significant influence in reducing the number of poor people in districts/cities in Aceh Province in 2011-2019.

c. The Special Autonomy Fund has no effect in reducing the number of poor people in districts/cities in Aceh Province in 2011-2019.

d. Gross Regional Domestic Product has a significant influence in reducing the number of poor people in districts/cities in Aceh Province in 2011-2019.

\section{Limitation of the Study}

The limitation in this study is that the independent variables analyzed are only seen for their direct influence on poverty, even though there is a possibility that there are variables that have an influence path with other variables outside the study.

\section{Declaration of conflicting interest}

The author declared no potential conflicts of interest with respect to the research, authorship and/or publication of this article.

\section{Funding}

The author received no financial support for the research, authorship and/or publication of this article. 


\section{References}

[1] Musliadi and A. Halim, "ANALISIS PENGARUH DANA OTONOMI KHUSUS, PENDAPATAN ASLI DAERAH, DAN BELANJA MODAL TERHADAP KEMISKINAN PADA KABUPATEN/KOTA DI PROVINSI ACEH TAHUN 20082012," Universitas Gajah Mada, 2015.

[2] M. Kadafi and Murtala, "PENGARUH PENDAPATAN ASLI DAERAH, DANA ALOKASI UMUM DAN DANA OTONOMI KHUSUS TERHADAP TINGKAT KEMISKINAN DI PROVINSI ACEH PERIODE 2010-2017," Ekon. Reg. Unimal, vol. 3, no. 2, pp. 23-31, 2020.

[3] Mohammed, Ahmed, and Salihu, "Expenditure and Internally Generated Revenue Relationship: An Analysis of Local Governments in Adamawa State, Nigeria. Journal of Arts, Science \& Commerce," J. Arts, Sci. Commer., vol. 6, no. 3, pp. 67-77, 2015.

[4] Muammar Ramadhan and E. F. Cahyono, "HUBUNGAN DANA PENANGGULANGAN KEMISKINAN PEMERINTAH DAN ZISWAF TERHADAP JUMLAH PENDUDUK MISKIN," J. Ekon. Syariah Teor. dan Terap., vol. 6, no. 7, pp. 1637-1643, 2019.

[5] H. Ranadireksa, Arsitektur Konstitusi Demokratik. Bandung: Fokusmedia, 2007.

[6] M. Harjowiryono, Pengembangan Sistem Pembiayaan Antar Pemerintah di Indonesia, Desentralisasi Fiskal di Indonesia Satu Dekade setelah Ledakan Besar. Jakarta (ID): DJPK, 2012.

[7] D. Sanur, "Implementasi Kebijakan Otonomi Khusus di Aceh [Implementation of Special Autonomy Policies In Aceh],” J. Polit. Din. Masal. Polit. Dalam Negeri dan Hub. Int., vol. 11, no. 1, pp. 65-83, 2020, doi: 10.22212/jp.v11i1.1580.

[8] Bisariyadi, "tinjauan ketatanegaraan penerapan otonomi khusus pada propinsi nanggroe aceh darussalam," Universitas Indonesia, 2003.

[9] R. Badrudin and I. Kuncorojati, "the Effect of District Own-Source Revenue and Balance Funds on Public Welfare By Capital Expenditure and Economic Growth As an Intervening Variable in Special District of Yogyakarta," J. Manaj. dan Kewirausahaan, vol. 19, no. 1, pp. 54-59, 2017, doi: 10.9744/jmk.19.1.54-59.

[10] C. Marista, "HUBUNGAN SIMULTAN PERTUMBUHAN EKONOMI DAN KEMISKINAN DI PROVINSI LAMPUNG,” Universitas Lampung, 2018.

[11] Todaro and S. C. Smith, Pembangunan Ekonomi, Edisi ke-1. Jakarta: Erlangga, 2015.

[12] M. F. Gumilang, "Analisis dampak alokasi dana desa terhadap kemiskinan di kabupaten bogor," 2017.

[13] Jolianis, "ANALISIS PENGARUH PAD , DAU DAN DAK TERHADAP KEMISKINAN PADA KABUPATEN / KOTA DI PROVINSI SUMATERA BARAT DENGAN PERTUMBUHAN EKONOMI SEBAGAI VARIABEL INTERVENING," J. Econ. Econ. Educ., vol. 4, no. 2, pp. 192-209, 2016.

[14] M. Mantsani, D. A. L. Rumodar, K. Syukriah, and S. Soegiarto, "Determinan Kemiskinan Provinsi Aceh Tahun 2017," Semin. Nas. Off. Stat., vol. 2019, no. 1, pp. 466-477, 2020, doi: 10.34123/semnasoffstat.v2019i1.17. 